10 years ESJ

Special edition

\title{
The Role of Needs Analysis in English for Academic Purposes in Higher Education
}

\author{
Paola Clara Leotta, PhD \\ University of Catania, Italy \\ Tamari Dolidze, PhD \\ Batumi State Maritime Academy, Georgia \\ Pegaso International, Italy
}

Doi:10.19044/esj.2022.v18n5p8

Submitted: 29 September 2021

Accepted: 05 November 2021

Published: 21 February 2022
Copyright 2022 Author(s)

Under Creative Commons BY-NC-ND

4.0 OPEN ACCESS

Cite As:

Leotta P.C. \& Dolidze T. (2022). The Role of Needs Analysis in English for Academic Purposes in Higher Education. European Scientific Journal, ESJ, 18 (5), 8.

https://doi.org/10.19044/esj.2022.v18n5p8

\section{Abstract}

Despite the established importance of English worldwide, and notwithstanding the fact that in expanding circle countries (defined as expanding or extending circle countries those countries where English is used as a foreign language), English for Academic Purposes plays an increasingly important role. Studies on the linguistic needs of university students are still lacking their perspective, at least in Italy, where students studying English language in Higher Education institutions are expected to gain access to the discourses of the academia via language competence. For this reason, the present paper reviews the theoretical and practical bases of English for Academic Purposes in order to provide further thought-provoking ideas based on a study carried out in the Italian university context. As far as method is concerned, due to the spread of the COVID-19 pandemic, the study was conducted through Google Forms. The results of the authors' questionnaire model are presented and analysed for the purpose of this research. Findings demonstrate both the complex network of elements that play a significant role in determining the needs of EAP students in Italy, and the unavoidable necessity to set priorities. It is a fact that needs in a learner-centred system are not static. In addition, learning EAP is bound to mean learning to be an 
independent learner.

Keywords: EAP, Needs analysis, student-centredness, transnational education, teacher's role

\section{Introduction}

Despite the established importance of English worldwide, and notwithstanding the fact that in expanding circle countries (Braj Kachru (1988, p.5) defines as expanding or extending circle countries those countries where English is used as a foreign language), English for Academic Purposes plays an increasingly important role. Studies on the linguistic needs of university students are still lacking their perspective, at least in Italy, where students studying English language in Higher Education institutions are expected to gain access to the discourses of the academia via language competence. For this reason, the present paper reviews the theoretical and practical bases of English for Academic Purposes in order to provide further thought-provoking ideas based on a study carried out in the Italian university context.

Currently, it is assumed that English is fundamental in Higher Education. For this reason, two paths are proposed in parallel:

- International degree programmes, the subjects of which are entirely taught in English (Barbieri, 2019 );

- Syllabi of EAP, whose aim is the development of written and oral communication skills in the academic field, taking inspiration from authentic situations and texts in various disciplines and specialist fields.

The aim is certainly to help students acquire knowledge of the English language with a view to subsequent achievement of their academic, professional, and social integration objectives.

The EAP curricula for students within the courses in Tourism, Psychology and Educational Sciences at the University of Catania includes a total of 600 (both Italian and foreign) students. It comprises 1 to 2 EAP courses, which are both taught by native speakers (for General English) and content area lecturers (whose classes are more discipline-specific), for at least 3 hours per week and are worth from 4 to 10 credits. The main purpose for teaching EAP is to enable students to read discipline-specific texts in English, be present at conferences, and/ or translate articles into Italian.

\section{Review of Literature}

It should be emphasised that an EAP course can be effective only when teachers are adequately trained and attentive to learners' needs, and able to choose the most suitable materials. The concept of motivation is present within 
the ESP context in relation to the materials chosen for teaching. In the ESP process, each step is linked to the next and the previous one. In fact, the choice of already existing materials or the realisation of other suitable ones can only occur when the English language learners' needs are identified. If the materials are adequate to the students' expectations, they will be more motivated to study and achieve educational success. If the materials available, however, do not meet students' needs and are boring, they might feel that their language study is a waste of time. To avoid this, conducting an analysis could be advantageous to allow teachers to fully understand students' points of view, their concerns and their willingness to succeed in acquiring the proposed skills. As far as textbooks are concerned, however, there is high uniformity, with a noticeable emphasis on developing reading skills. They commonly include reading excerpts related to students' academic fields, followed by exercises on comprehension, vocabulary, and translation. All this explains why the present study was carried out: firstly, to broaden the scope of studies undertaken so far around students' and instructors' perceptions of their language learning needs, and secondly to analyse the perception of EAP learners at the University of Catania, from different though related academic backgrounds.

The Needs Analysis conducted in the degree courses, therefore, had on the one hand, the aim of detecting the real linguistic-communicative needs of students in reference to the social or professional group to which they belonged at the time of the survey, and on the other, the application-didactic purpose of creating guidelines to structure our didactic action. In the field of applied linguistics, different models of needs analysis (Richterich, 1973; Munby, 1978; Richterich \& Chancerel, 1978; Chambers, 1980; Long, 2015) have been used in identifying the language tasks that learners have to perform in their professional activities. If, in the language teaching, Needs Analysis is connected to the communicative approach, in the TBLT (task-based language teaching) it becomes one of the constitutive logical units, as it is precisely from this pedagogical tool that the syllabus is structured, and the teaching is organized (Long, 2015, p. 88). In TBLT, in fact, through the analysis of linguistic needs, teaching tries as far as possible to make the act of learning coincide with the real communicative act (Cortés Velásquez \& Nuzzo, 2018). Thus, the Needs Analysis is truly the first step in truly student-centred teaching.

Based on the relevant literature in the area, the paper reviews the mainstream framework of EAP needs classification and analysis before it proposes a model for application in the field. Within the European education systems and the Italian system in particular, students in university classes should not remain encapsulated inside their own cultural universes. They should develop intercultural thinking skills, so as to be trained in 
understanding the perspectives of fellow students and their different worldviews (Sapir-Whorf Hypothesis, Carassai, \& Crucianelli, 2017), as well as in using the English language as a shared code.

This objective can only be achieved:

- If opportunities and spaces are built for interaction among peers through an intercultural approach,

- If the local context is made more attentive to the students' needs.

An intercultural approach in education should represent an occasion for shared development among people with different cultures and languages, to achieve positive coexistence. In this case, the teacher's role is that of a cultural mediator (Katan, 1999) who takes students' needs (not only linguistic, but also academic) into account (Swales, 2003, p. 150-164) and practises scaffolding (Vygotsky, 1980) as a guidance to the development of cognitive and social skills. This approach is strictly linked to the concept of studentcentredness (Hutchinson \& Waters, 1987:72; Robinson, 1991; Savignon \& Wang, 2003). Therefore, this seems to be the main basic principle of English language teaching today, as it is responsive to learners' needs. In fact, it is centred on the principle that «learning is totally determined by the learner».

Learning is seen as an "internal process" that takes place when someone receives new information and interprets it based on previous knowledge. The priority is the importance given to the students, understood both in terms of competence, which is the basis of the ability to learn, and in terms of how they develop this competence. This approach follows a set of questions addressed to the students, in relation to which it will be possible to define which way the teaching will have to be imparted, even if deviating from the final objective, but always keeping it in consideration. For this reason, the design of an EAP course is a dynamic process, characterized by flexibility, considering that there is no "standard student" in Higher Education (Martin \& Ellis, 2012).

\section{Method}

Due to the spread of the COVID-19 pandemic, the study was conducted through Google Forms. In January 2021, an anonymous questionnaire was administered to a sample of 59 Italian students aged 19 to 28 (41 women and 18 men) who study English as a foreign language. Their provenance, in terms of the University location and study course, can be summarised in Table 1 (Appendixes).

As for the choice of the instrument, advantages that can be drawn from the administration of a questionnaire have been considered: speed in the collection of information, and accessibility to participants. The questionnaire used in this study is a modified version of the questionnaires designed by Ali 
Khan (2007) and Balint (2010). Some Items were added in relation to the needs of the study, while other Items proposed by the authors have been deleted because they are not relevant to the context under consideration.

The completion of the questionnaire took participants about 10 minutes. The questionnaire consists of three parts and 43 Items.

The first one is about personal information (Items $1-7$ ), i.e., age, sex, University, and pre-requisites in English language competence. The second is about the participants' current interest in the English language (Items 8 - 19) which investigates the level of language knowledge that students reported that they have, the perception that English classes at the university are useful or not, and the reasons why they use the language daily.

Finally, the last part of the questionnaire explores the future objectives (Items 20 - 43) based on a list of activities in which every student is required to assess their usefulness in the English language in the future. Items 9, 14-19 and 22-43 were administered in the form of a 6-point Likert scale. Accordingly, one must express a degree of agreement or disagreement, or the degree of importance attributed to a statement. The other Items consist of multiple-choice sentences or questions in which participants insert other options, by using the function "Other", if those presented are not suitable for them. The questionnaire submitted is provided in the part of the Appendixes entitled: Questionnaire on Needs Analysis.

\section{Results}

The data obtained from the administration of the questionnaire were analysed using a quantitative analysis, through which it was possible to identify the differences and similarities among the participants. This type of analysis was preferred over the qualitative type, because it was more compatible with research questions. Beyond that, the aim was to identify the perception of as many students as possible. For this reason, quantitative analysis is certainly an excellent method to obtain statistical data. As specified above, the questionnaire administered is divided into three sections. Based on this framework, it is now possible to have a clearer view of our results.

\section{Personal Information (Items 1 - 7)}

This section of the questionnaire (from 1 to 7 ) aims at collecting personal information, such as age, gender, information about the course of study attended and the University City. Finally, it investigates information about whether students have studied English and, if so, where and for how long. As regards this, 56 students $(94.9 \%)$ said they had studied English. The majority of these $(91.1 \%)$ said they had studied it at school, $28.6 \%$ said they had studied it at a private language school, while $21.4 \%$ had self-studied. In Item 6 , participants could choose more than one answer depending on where 
they had studied the language. In fact, most of the sample reported that they had studied English at school, and/or at a private language school or as a selflearner while still at secondary school. As for Item 7, 56 participants also replied to this question, of which $64.3 \%$ said that they had studied English for longer than 8 years, whereas a smaller percentage $(16,1 \%)$, but still quite numerous, reports that they have studied it for only 5 years. Regarding the second section (including Items from 8 to 19), an attempt has been made to gather information about current knowledge of the English language, the reasons why it is used, and why participants want to learn it. Item 9, in continuity with the previous section, refers to the general level that people believe they have in their use of English. This Item is presented as a six-point Likert scale from very poor to very good. $42.4 \%$ of research participants believe they have reached a good level of knowledge of the language, while $23.7 \%$ believe their level is poor. It is only $6.8 \%$ of the total that, instead, reports having a very good level.

The purpose of Item eight is to understand the reasons why they want to study English in relation to their future. 33.9\% said they needed it for their own personal interest, $30.5 \%$ to get a job and $20.3 \%$ to travel. In addition, $11.9 \%$ reported that they needed it mainly to pass exams. A smaller percentage (3.4\%) of students believe that English is more useful for communicating with foreign friends. The answers seem to suggest that women participants are interested in English for their own benefit, on the contrary, men feel they need it in order to get a job.

Item 10 refers to areas in which reference is made to the English language on a daily basis. Most (64.4\%) students report that study is the main reason why they need more English, $62.7 \%$ use it to listen to music, $49.2 \%$ to watch films or TV series and $40.7 \%$ to travel. A smaller number report using English to socialise (20.3\%) and for work purposes (16.9\%).

Items 11, 12, and 13 jointly investigate the perception of Englishspeaking lectures. In particular, questions 11 (If studying English at the university were optional, I would have chosen...) and 12 (I believe that the contents of the English course that I attend/have attended at the university are...) are complementary, because they have as their objective the definition as to whether students consider the courses, the materials presented, and if the teaching methods are appropriate to their learning needs.

$50.8 \%$ of the participants consider it profitable to attend the English courses offered by the respective universities, while a good $23.7 \%$ report that they would have preferred not to attend the course. Finally, 24.5\% replied "I don't know". From this data, it can be assumed that many students do not attend university lectures because they are not interested or because they are engaged in work activities. 
Consistent with the findings of Item 11, the responses to Item 12 reflect a generally positive view of English courses. In fact, the majority of students reported that they considered English classes to be interesting (28.8\%) and/or useful (49.2\%). However, a relevant percentage finds them boring (10.2\%) and/or unnecessary (18.6\%).

In addition, Item 13 on English-speaking university classes aims to investigate the students' preference between traditional lectures, which are lectures where teachers explain and students listen and take notes, and dynamic classes, i.e., interactive classes where students participate actively and are involved in the activities proposed by the teachers. The results show that $86.4 \%$ of students would prefer interactive classes, which would seem to be in line with the assumptions of teaching English for Academic Purposes intended as a student-centred and intercultural approach. It is only $10.2 \%$ who report preferring traditional lectures, which they evidently consider to be more suited to their own learning styles. One of the students reports that s/he would prefer workshops to communicate with a native speaker tutor so as to acquire a better pronunciation and to confront with a native speaker about their culture. Finally, a non-attending student answers s/he does not know.

The last part of this section concerns Items 14 to 19 presented in the form of a 6-point Likert scale in which participants express their degree of agreement or disagreement. The purpose of these statements is to investigate the objectives that students have regarding their use of the English language. The responses to these Items have been divided according to gender in order to identify certain differences between them. There were 41 women (69.5\% of the sample) and 18 men (30.5\% of the sample). The data show that both women and men agree that English is a very useful language for communication in foreign countries (Item 19). They also agree that learning English is a pleasant challenge (Item 16) and one which is also advantageous to achieve a Higher Education level (Item 17). As far as Item 18 is concerned, the participants, both men and women, agree that studying English is important when seeking emplyment after graduation. Some gender differences stand out in Items 14 and 15. Moreover, women report that their goal after graduation is not to find a job abroad, whereas men may take this possibility into consideration.

The results of Item 20 show no gender differences. In fact, in both cases, the participants unanimously report that speaking is the fundamental ability to learn in order to improve their skills. Almost marginal importance is given to all other skills, such as reading, listening, writing, grammar, and vocabulary.

As for Item 21, participants were asked to choose, if considered necessary, more than one response among those submitted. The purpose of this Item is to clarify skills students consider to be deficient, and consequently would like to further develop. Similarly to the answers given to the previous 
Item, data showed that there are no particular gender differences, as both men and women felt they needed to improve their speaking skills, followed by listening skills, and vocabulary. However, little importance is given to reading, writing, and grammar. In other words, the data just presented highlight a particularly important situation. On the one hand, students believe that the fundamental skill to possess is that of speaking and, at the same time, this skill is also what they would like to further develop. This suggests that students who have taken part in this study wish, for various reasons, to study English in order to be able to communicate. Surely, this should make one think about the fact that university English classes do not often give much space to students to communicate through the English language, not just among themselves, but also with teachers. These are probably the reasons why students do not feel competent enough to communicate. It is precisely this fact that should make us reflect on the possibility of stimulating more the speaking skill during the lessons.

In the last section, Items 22 to 43 are presented by means of a 6-point Likert scale to investigate the degree of importance that is attributed to a series of activities that allow the use of the English language, and also encourage the development of new skills that are useful to students' future.

In this part of the questionnaire, various activities are reported, but their focus in on the use of the English language: to study vocabulary and grammar, discuss general and current issues with fellow students at university or with foreigners, communicate when they are abroad, write documents or emails, do research, read scientific articles and newspapers, read e-mails and textbooks, and listen to lectures or conferences. In general, the participants evaluate all these activities in a positive way and consider them fundamental to mastering the English language in the future. Among all the activities presented, the ability to do research in English (69.5\%) seems fundamental. In addition, activities relating to the reading of working documents and/or emails and scientific articles on the Internet (54.2\%) are considered equally important. Finally, other activities considered extremely useful are certainly those related to the study of specialised vocabulary and the possibility to communicate in English at a conference (50.8\%). However, activities such as conversation with fellow students at university and the reading of e-mails written in English by foreign friends are not considered fundamental.

\section{Discussion}

Needs analysis for EAP, particularly when conducted on a large scale at university, is indeed a multifaceted and often arduous task that attempts to address the wide range of requirements for the effective learning/teaching of the language in question. This is further compounded by the fact that from a pragmatic point of view, the scale of the analysis can range from a short 
interview, with one or two target course participants for a half-day EAP course, to a full-fledged research project, to produce a precise set of specifications for a whole programme of prospective courses catering for students from several academic disciplines at university (Coleman, 1988). How much information does the analyst endeavour to cover? Alternatively, what aspects can he/she "safely" leave out? The same questions are bound to arise when needs assessment is deployed as an EAP course/programme evaluation procedure, and yet again made it more difficult given the scale of operations and the timing of the analysis. Perhaps, needs analysis in EAP is as complex as the area of theory and practice it serves. Furthermore, it is justified in the main by the same guiding principle of cost-effectiveness of operations within the context of prioritising educational practice so that what the student learns is motivating because it is unequivocally relevant to his/her immediate academic needs. As a matter of fact, our findings have demonstrated both the complex network of elements which play a significant role in determining the needs of EAP students in Italy, and the unavoidable necessity to set priorities.

Indeed, the study of English through EAP courses is different from the study of English through courses in General English. In fact, it is supposed that EAP courses are based on the real needs that the student manifests and on current or future reasons that drive him/her to learn the language. However, despite the fact that, in recent years, EAP courses have become increasingly integrated within the university context, we should keep in mind that there are still many Degree Courses at the University of Catania and other Universities in Italy which do not provide such courses. This probably explains why some students are not motivated to attend lectures.

In general, it is clear that the majority of participants consider the English language essential for their future. In fact, the material obtained from this study points out that, nowadays, English has become part of everyday life. In addition to studying, students need it for many other reasons such as travelling, listening to music, and watching films or TV shows. To confirm this, the study participants report that they mostly need to study English for personal interest and to find an employment. In addition, the importance given to communication skills would confirm Richterich's (1973) statement that needs manifest as a state of imbalance that arises because of the need to communicate. On the one hand, it is precisely to note that this skill is considered as the most important, and also the one to further practise during English language courses.

In general, our findings support the view that students greatly need to increase their general proficiency in English. Learning a language is certainly not a simple task but, thanks to the help of teachers and the possibility to customise EAP courses according to the individual needs of the students, it can be transformed into a pleasant goal to pursue. EAP teachers' motto could 
certainly be: "Tell me what you need English for, and I will tell you the English that you need". (Hutchinson \& Waters, 1987).

\section{Conclusion}

Two final points, however, about the EAP learners' needs must be noted. Firstly, needs in a learner-centred system are not static. Just as students' wants, desires and expectations have the proclivity for change over time, so do their needs. Hence, the importance of programme/materials evaluation cannot be overstated. Needs analysis must not, as mentioned earlier, be seen as a one-off procedure to be conducted only before programme design. On the contrary, it must be an ongoing process of negotiation that involves the learners' right from the start and which forms an integral part of programme design and evaluation. This is done so that the current courses of instruction should continue to be sensitive based on the expectations of the parties concerned.

Secondly, the Higher Education student's expectations, other than being academic/occupational, situational, personal and individual, are also bound to be cultural-educational in such a way that he/she must have been conditioned to the way in which he/she and other people learn and are taught English in their society. So, an EAP course would be different provided that students be "educated into coming to terms with a novel experience" (Strevens, 1988, p. 7). Therefore, learning EAP is bound to mean achieving the goal of independence for the student's own learning. In the final analysis, that is what counts. In addition, our approach has aimed to deconstruct some stereotypical images of "inner circle" cultures, to discover their complexity and establish a true intercultural dialogue through the development, by the students, of their ability to decentralise, reject prejudices, negotiate, think as intercultural mediators, and act as better human beings.

\section{References:}

1. Ali, K. H. (2007). A Needs Analysis of Pakistani Boarding Schools Secondary Level Students for Adoption of Communicative Language Teaching. M.A. Dissertation School of Arts \& Education of Middlesex University London.

2. Balint, M. (2010). Assessing Students' Perceived Language Needs in a Needs Analysis. PAAL Journal, 26 - 43.

3. Barbieri, F. (2019). Università, in Italia una laurea su 10 «parla» solo inglese. Il Sole 24 ore retrieved from https://www.ilsole24ore.com/art/universita-laurea-10-parla-soloinglese-ACL4vBT?refresh_ce=1. (29 June, 2019). 
4. Berwick, R. (1989). Needs assessment in language programming: from theory to practice. In R. Johnson (ed.), The Second Language Curriculum. Cambridge: Cambridge University Press: 48-62.

5. Bridley, G. P. (1989). The role of needs analysis in adult ESL programme design. In R. Johnson (ed.), The Second Language Curriculum. Cambridge: Cambridge University Press: 63-78.

6. Brown, J. D. (1995). The Elements of Language Curriculum: A Systematic Approach to Program Development. Boston: Heinle \& Heinle.

7. Carassai, M. \& Crucianelli, E. (2017). Linguaggio e Relatività. Edward Sapir - Benjamin Lee Whorf. Roma: Castelvecchi.

8. Chambers, F. (1980). A re-evaluation of needs analysis in ESP. ESP Journal, I, 1: 25-33.

9. Coleman, H. (1988). Analysing language needs in large organisations. English for Specific Purposes, J, 3: 155-69.

10. Cortés Velásquez, D. \& Nuzzo E. (2018). (eds) Il task nell 'insegnamento delle lingue. Percorsi tra ricerca e didattica al CLA di Roma Tre. Roma: RomaTrE-Press.

11. Hutchinson, T. \& Waters, A. (1987). English for Specific Purposes: A learning-centred approach. Cambridge: Cambridge University Press.

12. Juan, L. (2014). Literature Review of the Classifications of "Needs" in Need Analysis Theory. International Journal of Education \& Literacy Studies, 2 (3) Australia: AIAC.

13. Kachru, B. (1988). The sacred cows of English. English Today 16, 38.

14. Katan, D. (1999). Translating Cultures, An Introduction for Translators, Interpreters and Mediators. Manchester: St. Jerome Publishing.

15. Long, M. (2015). Second Language Acquisition and Task-Based Language Teaching. Wiley: Blackwell.

16. Martin, K. I. \& Ellis, N. C. (2012). The roles of phonological shortterm memory and working memory in L2 grammar and vocabulary learning. Studies in Second Language Acquisition,34: 379-413.

17. Maslow, A. (1954). Motivation and Personality. New York: Harper.

18. Munby, J. (1978). Communicative Syllabus Design. Cambridge: Cambridge University Press.

19. Richterich, R. (1973). A Model for the Definition of Language Needs of Adults Learning a Modern Language. Strasbourg: Council of Europe. 
20. Richterich, R., \& Chancerel, J.-L. (1978). Identifying the needs of adults learning a foreign language. Strasbourg: Council of Europe/Oxford: Pergamon.

21. Robinson, P. (1991). ESP today: A Practitioner's Guide. Hemel Hempstead, UK: Prentice Hall.

22. Savignon, S. J., \& Wang, C. (2003). Communicative language teaching in EFL contexts: Learner attitudes and perceptions. International Review of Applied Linguistics in Language Teaching, 41(3): 223-249.

23. Strevens, P. (1988). ESP after twenty years: A re-appraisal. In M Tikoo (ed.), ESP: State of the art: 1-13.

24. Swales, J.M. (2002). Integrated and Fragmented Worlds: EAP Materials and Corpus Linguistics. In: J. Flowerdew, (ed.) Academic Discourse: 150-164. Vygotsky, L. (1980). Mind in Society. The Development of Higher Psychological Processes. Cambridge, Massachusetts: Harvard University Press.

25. West, R. (1997). Needs Analysis: State of the Art. In Howard, R.\& Brown, G.,Teacher Education for LSPClevedon, UK: Multilingual Matters: 68-79.

26. White, R. (1988). The Elt Curriculum: Design, Innovation, and Management: Design, Innovation and Mangement. Oxford: Blackwell.

27. Widdowson, H. (1981). English for Specific Purposes: Criteria for Course

28. Design. In Selinker, L. Tarone, E., \& Hanzeli, V., English for Academic and Technical Purposes: Studies in Honor of Louis Trimble: Rowley, Massachusetts: Newbury House Pub: 1-11. 
European Scientific Journal, ESJ ISSN: 1857-7881 (Print) e - ISSN 1857-7431 February 2022

Bridging Language, Medicine, and Law

Table 1

\section{Appendix}

\begin{tabular}{|c|c|c|c|c|}
\hline \multicolumn{3}{|l|}{ Department } & $\begin{array}{l}\text { No. of } \\
\text { participants }\end{array}$ & Percentage \\
\hline $\begin{array}{l}\text { Educational } \\
\text { Science } \\
\end{array}$ & $\begin{array}{ll}\begin{array}{l}\text { Psychological } \\
\text { and Techniques }\end{array} & \text { Sciences } \\
\end{array}$ & Catania & 32 & $54,2 \%$ \\
\hline \multirow{4}{*}{ Humanities } & $\begin{array}{l}\text { Foreign Languages and } \\
\text { Literatures. }\end{array}$ & \multirow{4}{*}{ Catania } & 1 & \multirow{4}{*}{$6,7 \%$} \\
\hline & $\begin{array}{l}\text { European, Euro-American, } \\
\text { and Eastern Languages and } \\
\text { Cultures. }\end{array}$ & & 1 & \\
\hline & Modern Literature & & 1 & \\
\hline & Communication Sciences & & 1 & \\
\hline \multirow{3}{*}{\multicolumn{2}{|c|}{ Medicine }} & Catania & 4 & \multirow{3}{*}{$10,2 \%$} \\
\hline & & Catanzaro & 1 & \\
\hline & & Messina & 1 & \\
\hline Business Eco & mics & Catania & 2 & $3,4 \%$ \\
\hline \multirow{2}{*}{\multicolumn{2}{|c|}{ Law }} & Catania & 1 & \multirow{2}{*}{$3,4 \%$} \\
\hline & & Pavia & 1 & \\
\hline \multirow{6}{*}{ Engineering } & Informatics & \multirow{3}{*}{ Catania } & 1 & \multirow{6}{*}{$10,2 \%$} \\
\hline & Civil & & 1 & \\
\hline & Construction & & 1 & \\
\hline & Bio-engineering & Pavia & 1 & \\
\hline & Chemical & \multirow{2}{*}{ Milano } & 1 & \\
\hline & Aerospace & & 1 & \\
\hline \multirow{7}{*}{ Other Depts. } & Occupational Therapy & \multirow{4}{*}{ Catania } & 1 & $1,7 \%$ \\
\hline & Computer Science & & 1 & $1,7 \%$ \\
\hline & Singing & & 1 & $1,7 \%$ \\
\hline & $\begin{array}{l}\text { Planning and } \\
\text { Environmental Protection }\end{array}$ & & 1 & $1,7 \%$ \\
\hline & Biological Sciences & Messina & 1 & $1,7 \%$ \\
\hline & Interior Design & Milano & 1 & $1,7 \%$ \\
\hline & $\begin{array}{l}\text { Physical Education and } \\
\text { Sports Science }\end{array}$ & Genova & 1 & $1,7 \%$ \\
\hline \multicolumn{3}{|l|}{ Total } & 59 & $100 \%$ \\
\hline
\end{tabular}




\section{Questionnaire on Needs Analysis}

Personal Information

1. Age:

2. Sex:

Female

Male

Not specified

3. University (indicate the city):

4. Degree course (indicate if it is a registered denomination and whether it is a three-year or master's degree or a single cycle course):

5. Have you studied English before?

$$
\text { Yes }
$$

No

6. If the answer to Item 5 is "yes", where did you study the language? (You can choose more than one answer)

At school

As a self-learner

At a school of English

Other

7. If the answer to Item 5 is "yes", for how long (refer to years)?
1
2
3
4
5
6
7
$8+$

\section{Current Interest in the English Language}

8. I need to study English ...
To pass exams
To speak to foreign friends
To travel
To get a job
For personal interest
Other

9. My current overall competence in English is:
Very poor
Poor
Fair
Good
Very good
Excellent 
European Scientific Journal, ESJ ISSN: 1857-7881 (Print) e - ISSN 1857-7431 February 2022 Bridging Language, Medicine, and Law

10. I use English to... (more than one answer is possible)

Study

Socialise

Watch films/TV series

Listen to music

Work

Travel

Other

11. If studying English at university was optional, I would choose...

To attend the course

Not to attend the course

I don't know

Other

12. I believe that the contents of the English course that I attend at university are ... (select maximum of 2 answers)

Interesting

Useful

Boring

Useless

I don't know

Other

13. What kind of classes would you like to attend at university to learn English?

Lectures, where teachers speak, and students listen to

Interactive classes, where students participate actively and are involved in numerous activities.

Other

From Item 14 to 19, answer using the following scale:

1. Strongly disagree

2. Disagree

3. Somewhat disagree

4. Somewhat agree

5. Agree

6. Strongly agree 
European Scientific Journal, ESJ ISSN: 1857-7881 (Print) e - ISSN 1857-7431 February 2022

Bridging Language, Medicine, and Law

\begin{tabular}{|l|l|l|l|l|l|l|}
\hline $\begin{array}{l}\text { 14. After graduation, I aim to find a job that requires } \\
\text { English. }\end{array}$ & 1 & 2 & 3 & 4 & 5 & 6 \\
\hline $\begin{array}{l}\text { 15. After graduation, I aim to work in a country where } \\
\text { English is spoken. }\end{array}$ & 1 & 2 & 3 & 4 & 5 & 6 \\
\hline 16. Learning English is a challenge I like. & 1 & 2 & 3 & 4 & 5 & 6 \\
\hline $\begin{array}{l}\text { 17. I want to learn English to acquire a higher level of } \\
\text { education. }\end{array}$ & 1 & 2 & 3 & 4 & 5 & 6 \\
\hline $\begin{array}{l}\text { 18. I think that studying English is important to get a good } \\
\text { job after graduation. }\end{array}$ & 1 & 2 & 3 & 4 & 5 & 6 \\
\hline $\begin{array}{l}\text { 19. I believe that studying English is useful to } \\
\text { communicate in many foreign countries. }\end{array}$ & 1 & 2 & 3 & 4 & 5 & 6 \\
\hline
\end{tabular}

\section{Future Objectives}

20. Which of the following do you think is most useful to learn and improve your English language skills?
Reading
Listening
Speaking
Writing
Grammar
Vocabulary

21. Which of the following skills would you like to develop most? (Select maximum of 2 answers)

Reading
Listening
Speaking
Writing
Grammar skills
Vocabulary skills

From Item 22 to 43, answer based on how much you think each of these activities is useful for English learning in your future. Use the following scale to answer.

1. Not at all important

2. Not so important

3. Unimportant

4. Somewhat important

5. Quite important

6. Extremely important 
European Scientific Journal, ESJ ISSN: 1857-7881 (Print) e - ISSN 1857-7431 February 2022

Bridging Language, Medicine, and Law

\begin{tabular}{|c|c|c|c|c|c|c|}
\hline 22. To study English vocabulary. & 1 & 2 & 3 & 4 & 5 & 6 \\
\hline 23. To study English grammar. & 1 & 2 & 3 & 4 & 5 & 6 \\
\hline $\begin{array}{l}\text { 24. To speak about general topics and } \\
\text { current issues with class fellows in } \\
\text { English. }\end{array}$ & 1 & 2 & 3 & 4 & 5 & 6 \\
\hline $\begin{array}{l}\text { 25. To speak about general topics and } \\
\text { current issues with foreign people } \\
\text { in English. }\end{array}$ & 1 & 2 & 3 & 4 & 5 & 6 \\
\hline $\begin{array}{l}\text { 26. To speak English with hotel or } \\
\text { restaurant staff members when } \\
\text { travelling abroad. }\end{array}$ & 1 & 2 & 3 & 4 & 5 & 6 \\
\hline $\begin{array}{l}\text { 27. To write working papers in } \\
\text { English. }\end{array}$ & 1 & 2 & 3 & 4 & 5 & 6 \\
\hline $\begin{array}{l}\text { 28. To write e-mails to foreign friends } \\
\text { in English. }\end{array}$ & 1 & 2 & 3 & 4 & 5 & 6 \\
\hline $\begin{array}{l}\text { 29. To write work e-mails to foreign } \\
\text { people in English. }\end{array}$ & 1 & 2 & 3 & 4 & 5 & 6 \\
\hline $\begin{array}{l}\text { 30. To acquire the ability to do } \\
\text { research in English. }\end{array}$ & 1 & 2 & 3 & 4 & 5 & 6 \\
\hline $\begin{array}{l}\text { 31. To do group research during } \\
\text { university courses. }\end{array}$ & 1 & 2 & 3 & 4 & 5 & 6 \\
\hline $\begin{array}{l}\text { 32. To read work documents/ work e- } \\
\text { mails in English. }\end{array}$ & 1 & 2 & 3 & 4 & 5 & 6 \\
\hline $\begin{array}{l}\text { 33. To read scientific articles on the } \\
\text { Internet in English. }\end{array}$ & 1 & 2 & 3 & 4 & 5 & 6 \\
\hline 34. To read novels for fun in English. & 1 & 2 & 3 & 4 & 5 & 6 \\
\hline 35. To read newspapers in English. & 1 & 2 & 3 & 4 & 5 & 6 \\
\hline $\begin{array}{l}\text { 36. To read e-mails in English by } \\
\text { foreign friends. }\end{array}$ & 1 & 2 & 3 & 4 & 5 & 6 \\
\hline 37. To read textbooks in English. & 1 & 2 & 3 & 4 & 5 & 6 \\
\hline $\begin{array}{l}\text { 38. To attend English classes and take } \\
\text { notes. }\end{array}$ & 1 & 2 & 3 & 4 & 5 & 6 \\
\hline $\begin{array}{l}\text { 39. To participate in a conference in } \\
\text { English. }\end{array}$ & 1 & 2 & 3 & 4 & 5 & 6 \\
\hline $\begin{array}{l}\text { 40. To watch TV programmes or films } \\
\text { in English. }\end{array}$ & 1 & 2 & 3 & 4 & 5 & 6 \\
\hline 41. To listen to music in English. & 1 & 2 & 3 & 4 & 5 & 6 \\
\hline $\begin{array}{l}\text { 42. To speak English with foreign } \\
\text { tourists. }\end{array}$ & 1 & 2 & 3 & 4 & 5 & 6 \\
\hline 43. To speak English at a conference. & 1 & 2 & 3 & 4 & 5 & 6 \\
\hline
\end{tabular}

